\title{
INDUCING EMPLOYEES TO LEAVE: A COMPARISON OF FOUR SEVERANCE OPTIONS
}

\author{
KAREN STRANDHOLM, KIM SCHATZEL, AND \\ THOMAS CALLAHAN
}

\begin{abstract}
This study examines the demographic, economic, and psychographic characteristics of 324 blue-collar workers who were offered four options for either retirement or severance from the organization. Consistent with previous research, individuals who accepted retirement options have more organizational tenure and believed that the packages would provide stable financial futures. A key finding for those who accepted the nonretirement options is that comparable employment would be available. The study concludes with research limitations and suggestions for future research.
\end{abstract}

Keywords: turnover, severance packages, early retirement

\section{Introduction}

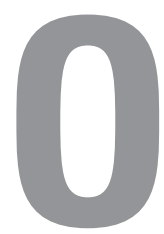

rganizations downsize for two basic reasons. The first reason is to reduce costs in response to a financial crisis such as a recession (Zatzick, Marks, \& Iverson, 2009). The second reason is to improve long-term competitive advantage "by improving efficiencies, taking advantage of new technologies, changing the skills of the workforce, or restructuring the organization" (Zatzick et al., 2009, p. 80). In both types of downsizing, the ultimate goal is to improve organizational performance through the strategy of workforce reduction.

However, research results are mixed as to whether downsizing through workforce reduction improves performance (e.g., Cascio, 2002; Datta, Guthrie, Basuil, \& Pandey, 2010; Guthrie \& Datta, 2008; Marks, 2006). Researchers generally believe that declines in employee morale caused by these reductions often result in performance declines (Cascio, 2002; Mishra, Spreitzer, \& Mishra, 1998). These declines in employee morale manifest themselves in a variety of ways. For example, turnover increases because of downsizing (Iverson \& Zatzick, 2011; Trevor \& Nyberg, 2008). Also, some surviving employees feel guilt, fear, or anger, which impacts their productivity (Brockner, 1988, 1992; Iverson \& Zatzick, 2011; Marks, 2006). Customer satisfaction and loyalty also decrease after downsizing (Lewin, 2003, 2009; Williams, Khan, \& Naumann, 2011). On the other hand, some studies indicate that downsizing is associated with increased profits (Palmon, Sun, \& Tang, 1997), return on assets (Cascio, Young, \& Morris, 1997; Palmon et al., 1997), asset turnover, return on equity (Espahbodi, John, \& Vasudevan, 2000), and operating income to total assets (Yu \& Park, 2006).

Correspondence to: Thomas Callahan, Department of Management Studies, College of Business, University of Michigan-Dearborn, 19000 Hubbard Drive, Dearborn, MI 48126, Phone: 313.593.5109, Fax: 313.271.9836, E-mail: nahallac@umd.umich.edu. 
Appelbaum, Patton, and Shapiro (2003) maintain that successful downsizing attempts are differentiated from unsuccessful ones by the presence of a strategic approach. From this perspective, studies have highlighted the importance of adopting best practices to reduce the negative effects associated with downsizing (e.g., Brockner, 1992; Feldman, 1994; Mishra et al., 1998; Zatzick et al., 2009). Best practices include cutting costs without forced workforce reductions, providing accurate and honest information through communications,
In order for an

organization

to create an

appropriate mix

of options, it must

understand the

characteristics of

those individuals

who are likely to

accept each of the

options as well as

the characteristics

of those who are

likely to reject each

of the options. giving employees opportunities to provide feedback, and creating a fair and compassionate work environment (Zatzick et al., 2009). Of particular importance to this study is the best practice of workforce reduction without compulsory layoffs.

A common method to reduce the workforce without forced layoffs is to institute a variety of severance options, such as earlyretirement programs and buyouts (Muñoz-Bullón \& Sánchez-Bueno, 2010; Zatzick et al., 2009). An appropriate mix of these options, one that takes into account the composition of the workforce, allows an organization to downsize without the necessity of forced layoffs. Such a mix is important because the organization is better able to preserve its knowledge base through retaining senior employees while protecting the future talent base represented by employees with less experience (Cascio \& Wynn, 2004). In order for an organization to create an appropriate mix of options, it must understand the characteristics of those individuals who are likely to accept each of the options as well as the characteristics of those who are likely to reject each of the options.

Although there has been research on severance programs that offer incentives to quit the organization, this research primarily has focused on the characteristics of those individuals who are either retirement eligible or close to retirement eligible (e.g., Gowan, 1998; Hogarth, 1988; Kim \& Feldman, 1998). An adjustment of pension benefits has been the primary vehicle to induce retirement. Limiting research to this subsegment of the severance population does not represent the reality of today's downsizing practices (Cascio \& Wynn, 2004). Available severance packages now include lump-sum payments and post-employment educational support, in addition to the retirement-related incentives.

There appear to be no studies that include employees who have been offered an array of severance choices that include options attractive to employees across all age and tenure levels. One study that has focused on incentives for non-retirement-eligible employees has been Mehay and Hogan (1998), who assessed the effects of monetary incentives on the quit decisions of midcareer military personnel. Given these expanded severance choices, organizations must be able to predict the effectiveness of multiple severance options to improve human resource planning. Furthermore, having a holistic approach to severance options, as opposed to focusing on retirement- or near-retirementeligible employees, enables the organization to manage a diverse talent base.

The purpose of this article is to address a gap in the literature by determining the economic, demographic, and psychographic characteristics of employees who accepted or rejected an array of severance options. We examined four options designed to induce blue-collar employees to sever their relationships with the organization. The first option was a bonus offered to retirement-eligible employees to induce these individuals to retire (retirement-eligible incentive). The second option was a pre-retirement leave with pay offered to those employees who were within two years of retirement (paid-retirement furlough). The third option was limited to those employees age 55 or older with at least 10 years of credited service. These individuals were offered their accrued pension benefits plus temporary benefits, payable until age 62. However, because of the truncated years of service, the pensions for individuals in this group would be less than their full retirement 
pensions (reduced-benefit retirement). The last option, extended to all employees, was a lump-sum payment in exchange for termination from the organization (lump-sum payment).

\section{Theoretical Framework}

Image theory (Beach, 1993; Broughm \& Walsh, 2007; Feldman, 1994), life-cycle theory (Fields \& Mitchell, 1984; Hogarth, 1988; Mehay \& Hogan, 1998), and side-bet theory (Becker, 1960; Iverson \& Buttigieg, 1999) have been used by researchers to explain an individual's retirement decision.

Image theory has been proposed as a framework through which choice-decisions made by individuals contemplating separation from an organization can be explained. This theory maintains that individuals make decisions based on three considerations or images (Beach, 1993; Beach \& Frederickson, 1989; Feldman, 1994). The first image is the decision maker's image of how people should behave (Beach, 1993). This image is based on the decision maker's basic moral code, including values, ethics, and behavioral norms (Beach, 1993; Beach \& Frederickson, 1989). The second image is based on the decision maker's image of what he/she envisions for the future (Beach, 1993; Beach \& Frederickson, 1989). The final image is the strategy the decision maker develops to achieve the image of his/her future (Beach, 1993).

Generally, the image that an individual has for his/her future is to maintain a certain standard of living and have the ability to engage in valued activities (Feldman, 1994). According to image theory, the decision to accept a severance option is screened against the individual's moral code and this image (Beach, 1993). If the option is compatible with this image and is consistent with the individual's moral code, the option is likely to be accepted. Because it is difficult to imagine a situation in which acceptance of a severance package would create a moral conflict, recent research guided by image theory has focused on concepts other than those associated with a moral code (e.g., Broughm \& Walsh, 2007).
This image of maintaining a certain standard of living is also consistent with the premise of life-cycle theory. Life-cycle theory is a basic economic model providing that "a utility maximizing individual will, among other things, consider the present value of earning and retirement income to estimate the value of working another year versus retiring" (Hogarth, 1988, p. 22).

Side-bet theory also has been used to explain individual retirement decisions (Cho \& Huang, 2012). This theory is based on the idea that individuals attach themselves to organizations because of an increased investment made to the organization over a period of time (Becker, 1960; Iverson \& Buttigieg, 1999). As these investments increase, commitment to the organization also increases due to the unwillingness of individuals to lose investments in pension funds, organization-specific knowledge, and seniority (Iverson \& Buttigieg, 1999; Mathieu \& Zajac, 1990). When individuals have sufficient assets to retire, including pension assets, the sidebet theory is no longer relevant because these individuals are able to recoup their investments at Image theory has been proposed as a framework through which choice-decisions made by individuals contemplating separation from an organization can be explained. grams reduce the need for side-bets and accelerate the retirement decision.

The following hypotheses have been developed relying on life-cycle theory, image theory, and side-bet theory as explanations for retirement behaviors.

\section{Hypotheses}

\section{Financial Stability}

The belief in a stable financial future greatly influences the decision to retire (Bahrami, 1999; Kim \& Feldman, 1998). Image theory suggests that individuals are more willing to retire if they believe they are able to maintain their standard of living and have the financial ability to engage in valued activities (Feldman \& Turnley, 1995). Life-cycle theory 
(Hogarth, 1988) predicts that based on accumulated wealth and anticipated retirement income, individuals have an idea of the optimal age at which this retirement decision will occur. Research also shows that this optimal age will be lowered if individuals are offered a severance option that increases retirement benefits (Hogarth, 1988; Kim \& Feldman, 1998). Based on this research, if an individual believes that the severance option will provide for a stable financial future, the person is likely to accept an incentive to retire.

This evaluation of a stable financial future is equally likely even if the next step in the person's career is not retirement. Researchers have noted a push process in which work and/or life stressors cause employees to generate and evaluate alternatives (Bretz, Boudreau, \& Judge, 1994). Unacceptable levels of these stressors will cause individuals to consider these alternatives (Bretz et al., 1994). Organizational stressors include perceptions of the organization, compensation levels, and perceived internal promotional opportunities (Bretz et al., 1994; Lee \& Mitchell, 1994; Mobley, Griffeth, Hand, \& Meglino, 1979). All of these become salient in organizations that downsize (Devine, Reay, Stainton, \& CollinsNakai, 2003). Under these circumstances, these individuals are pushed to generate and evaluate alternative job opportunities. Severance options incentivize individuals to accept a job alternative that is perceived to provide a stable financial future.

Hypothesis 1: The belief that a severance option will provide a stable financial future is positively related to the decision to accept a severance option.

\section{Future Employment}

The availability of future employment reduces the uncertainty associated with leaving a current job. For those employees who are close to retirement and question whether they will have the resources to have a comfortable retirement, the availability of other employment may compensate for reduced retirement income (Feldman \& Turnley, 1995; Kim \& Feldman, 1998). Furthermore, postseparation employment reduces job-loss anxiety by providing structure to the retiree's life (Feldman \& Turnley, 1995; Kim \& Feldman, 1998). Kim and Feldman (1998) found that individuals who were planning on returning to part-time teaching positions at a large university were more likely to accept early retirement.

Employees who are offered a severance option generally work for employers who choose to downsize for a variety of reasons, including financial pressures, global competition, technological advancements, outsourcing, mergers, and/or business process reengineering (Koeber \& Wright, 2006). From an image theory perspective (Feldman, 1994), future employment at these organizations is uncertain. Individuals not eligible for retirement may view the available severance options as opportunities to transition to job alternatives. This is consistent with previous research on voluntary turnover, in which an individual's perceived ease of movement in the job market correlates with voluntary turnover (Bluedorn, 1982; Smith, Holtom, \& Mitchell, 2011; Steel \& Griffeth, 1989).

Hypothesis 2: Availability of other employment is positively related to the decision to accept a severance option.

\section{Expectations of Future Offers}

Research supports the premise that if an employee believes that a better retirement offer will be available at a later date, the employee will turn down the offer (e.g., Kim \& Feldman, 1998; Pencavel, 2001). From a life-cycle theory perspective, this is a basic economic decision that seeks to maximize future income (Hogarth, 1988). As long as future income will be maximized, individuals will be likely to take any of the severance options.

Hypothesis 3: A belief that better offers will not be available in the future is positively related to the decision to accept a severance option.

\section{Age}

Age is related to pension eligibility and as such is a predictor of retirement (Adams \& 
Beerh, 1998). Pension eligibility reduces the financial constraints associated with retirement (Adams \& Beerh, 1998). Research reports a positive relationship between age and acceptance of retirement options (Hardy \& Hazelrigg, 1999; Hogarth, 1988; Karoly \& Rogowski, 1994; Kim \& Feldman, 1998; Whelan, Ehrenberg, Hallock, \& Seeber, 2011). According to side-bet theory (Becker, 1960; Cho \& Huang, 2012), for those eligible for or nearing eligibility for retirement, the financial incentives associated with these options further reduce the financial risks associated with retirement.

However, age also has been shown to be negatively related to turnover (Adams \& Beerh, 1998). As people age, they are less likely to voluntarily leave their jobs because of maturity and family responsibilities (Steers, 1977). It also is argued that as people age, available work options become more limited (Adams \& Beerh, 1998). Due to these limited job opportunities, older individuals not eligible for retirement are unlikely to accept a severance option that is perceived to be insufficient to manage family responsibilities over the long term.

Hypothesis 4a: Age is positively related to the decision to accept either the retirement-eligible incentive or the paid-retirement furlough.

Hypothesis 4b: Age is negatively related to the decision to accept either the reduced-benefit retirement or lump-sum payment.

\section{Years of Service}

Organizational tenure also has been found to be negatively related to turnover (Van Breukelen, Van Der Vlist, \& Steensma, 2004; Whelan et al., 2011). Tenure is associated with a reduced desire to leave the organization or the inability to do so (Van Breukelen et al., 2004). This reduced desire can be explained by side-bet theory (Becker, 1960; Iverson \& Buttigieg, 1999). As tenure increases, individuals are less motivated to leave an organization due to their financial and emotional investments (Cho \& Huang, 2012;
Iverson \& Buttigieg, 1999; Mathieu \& Zajac, 1990). An offer to leave the organization that does not provide for the recoupment of these investments is not likely to be accepted.

However, when individuals have sufficient assets to retire, including pension assets, the side-bet theory is no longer relevant because these individuals are able to recoup their investments at retirement. In this instance, a severance option that includes financial incentives for full retirement makes tenure even less relevant (Becker, 1960).

Hypothesis 5a: Tenure is positively related to the decision to accept either the retirement-eligible incentive or the paid-retirement furlough.

Hypothesis 5b: Tenure is negatively related to the decision to accept either the reduced-benefit retirement or lump-sum payment.

\section{Wage Level}

Wage level is differentially related to the decision to retire (Adams \& Beerh, 1998). Lifecycle theory states that a key decision facing individuals is whether they are in a financial position to retire (Hogarth, 1988). Higher-wage individuals should be in a better financial position to retire than lowerwage individuals (Adams \& Beerh, 1998). A severance option that provides increased financial incentives to retire is an added reason for these individuals to leave the organization.

Research has found a weak relationship between low pay and turnover (Griffeth, Hom, \& Gaertner, 2000). However, a financial incentive to quit should strengthen this relationship as it provides an additional incentive for lower-paid employees to seek employment elsewhere to enhance their ability to achieve a stable financial future (Whelan et al., 2011).

Hypothesis 6a: Hourly rate is positively related to the decision to accept either the retirement-eligible incentive or the paid-retirement furlough.

Hypothesis 6b: Hourly rate is negatively related to the decision to accept either the reduced-benefit retirement or lump-sum payment. 


\section{Working Partner}

Retirement generally is a joint decision and is timed in such a manner that both partners retire at a similar time (Hogarth, 1988; Karoly \& Rogowski, 1994; Kim \& Feldman, 1998). A projected image for retirement is engagement in valued activities (Feldman, 1994). Having a working partner may limit the individual's ability to engage in these activities. Therefore, individuals who are close to or eligible for full retirement and have a working partner are less likely to accept an option resulting in full retirement (Bahrami, 1999; Hallberg \& Eklöf, 2010; Hogarth, 1988; Karoly \& Rogowski, 1994; Kim \& Feldman, 1998; Väre, 2006).

For younger individuals, marriage is often associated with increased family responsibilities (Adams \& Beerh, 1998). As these responsibilities grow, individuals become more reliant on the organization to meet these obligations and thus more committed to the organization (Iverson \& Buttigieg, 1999). However, a working partner who is able to shoulder part of this burden reduces reliance on the organization and increases the likelihood of accepting a severance option.

Hypothesis 7a: Having a working partner is negatively related to the decision to accept either the retirement-eligible incentive or the paid-retirement furlough.

Hypothesis 7b: Having a working partner is positively related to the decision to accept either the reduced-benefit retirement or lump-sum payment.

\section{Method}

\section{Sampling Frame}

The present study was part of a larger research project commissioned by a domestic manufacturer and its union to identify demographic, economic, and psychographic factors that predict union hourly workers' acceptances of an array of separation options. According to the manufacturer, the same union had represented the organization's hourly employees for over 70 years. This relationship had been generally cooperative, although there have been historical instances of animosity, in particular during the early years of the relationship. Hourly wages in this industry were more than 30 percent above the average manufacturing wage in the United States (Procon.org, 2009). This industry offered some of the most generous benefits packages in the manufacturing sector. The manufacturer, headquartered in the United States, is a global Fortune 100 company. At the time of this study, the manufacturer employed more than 70,000 union workers in North America. Beginning in the 1980s, the fortunes of this industry could be described as a cycle of boom and bust. Restructuring and downsizing, through layoffs and early-retirement programs, became common. Significant competition from manufacturers based in Europe and Japan persistently had decreased the world market share of the North American sector of the industry. Furthermore, competition from Chinese and Korean manufacturers had exacerbated the decline in these manufacturers' competitive positions in more recent times. Financial analysts were predicting potential bankruptcies or takeovers for the major original equipment manufacturers and their supplier bases in this industry. As a matter of fact, in more recent times, the supplier base has experienced major bankruptcies. Arguably, high labor costs in the North American sector of the industry were considered to be an important cause of the industry's decline in market share.

The packages in this study consisted of four options described previously. The retirementeligible incentive provided a bonus about equal to three-fifths of the total yearly wages for the average worker. The paid-retirement furlough provided up to two years of pay for those close to retirement. The reduced-benefit package provided supplemental wages until the age of 62 to those who were at least 55 years of age and had at least 10 years of service. The last package provided a lump-sum payment equal to approximately two years' wages to sever all ties with the organization. These packages were not equivalent in a strict monetary sense. The value of these packages was functions of the life circumstances of the employees. It is impossible to compare 
the value a retirement-eligible employee placed on three-fifths of a year's pay versus the value a less tenured individual placed on two years of pay, with no retirement benefits and a threat of layoff.

Surveys were mailed to individuals who had been offered and asked to consider one of the options. Therefore, the sample included both active and former employees of the organization, the latter group consisting of those who had accepted one of the packages. The mailing list included the individuals' names and home mailing addresses. The following actions were taken to promote participation and minimize bias:

1. The survey packet included a personalized cover letter that introduced the study, indicated that it was sponsored by the manufacturer and its union, and conducted by an academic institution. The letter detailed the potential value from the employees' participation in the study in determining future actions by the manufacturer and union. The employee also was told that his/her responses were confidential and anonymous. A prepaid postage return envelope was included with the survey, indicating the survey would be returned to the academic institution.

2. A follow-up card was sent 10 days after the initial mailing to remind the employee of the request for his/her participation. The follow-up card also included the name and telephone number of a contact person if a replacement survey was needed.

\section{Instruments}

The survey contained psychographic, economic, and demographic items. Items assessed included the belief that the package would provide a stable financial future, perceptions about the employee's ability to find another job, expectations that a better separation package would be offered in the future, anticipated support from spouses' or partners' incomes or employment, age, tenure, and hourly rate classification.

Two versions of the survey were constructed: one designed for active employees, those who had rejected the buyout, and the other designed for employees who had recently accepted one of the options. Content of the items on each survey was virtually the same, but the two instruments contained slight wording variations. For example, for active employees, the items assessing perceptions that the option would provide a stable financial future contained the future tense. For those who already had accepted one of the options, the items contained past tenses.

\section{Participants}

In preparation for a companywide offer of the four packages, facilities in two North American cities were selected for a pilot study. The purpose of this pilot study was to estimate the number of employees who would accept the offer, as well as their characteristics. All hourly union employees at the facilities in these cities were offered the four packages. For this part of the study, 189 former employees who had recently chosen one of the options were compared to 135 employees who had rejected the same packages. Data on these employees were available because the options had been offered at specific plants before offers were made to all employees of the organization. More males (86 percent) than females participated. The mean age of participants was between 50 and 54 years. Average tenure was between 20 and 24 years. All but 32 of the participants had completed at least a high school education. Those paid as unskilled workers (75 percent) outnumbered those paid as members of skilled trades. Approximately 65 percent of the participants worked on an assembly line.

The final response rate was 19 percent for this segment of the study. To assess nonresponse bias, we compared the responses from the earliest respondents (first quartile) with those from the latest respondents (fourth quartile). There were no significant differences for the demographic variables (age, tenure, hourly wage, and partnered status) between the two groups. This analysis was based on the premise that late-wave respondents would be more similar to nonrespondents. Therefore, the respondent characteristics of the late 
respondents were expected to be reasonably representative of nonrespondents (Armstrong \& Overton, 1977). To further assess nonresponse bias, procedures similar to those recommended by Lindner, Murphy, and Briers (2001) were employed. The independent variables associated with the hypotheses were regressed onto a variable representing the two groups: all those who responded before the reminder notice was sent and all those who responded after the reminder notice was sent. The results from this regression were not significant $\left(R^{2}=.01, F(7,392)=.66, p>.05\right)$ providing evidence that at least among these two groups, responses did not differ.

\section{Data Analysis}

Before administering the survey, summative scales were developed to represent perceptions about the likelihood of finding a replacement job, the level of partner support employees might expect, the adequacy of projected retirement income and/or stable financial future, and the likelihood that a better package would be offered in the future.

Confirmatory factor analysis indicated acceptable levels of convergent and discriminant validity for the variables in the model. Average variances extracted (AVEs) ranged from .68 to .84 , all above the minimum value of .50, indicating adequate discriminant validity (Bagozzi, Yi, \& Phillips, 1991). Composite reliabilities assessed the internal consistency of the measures (Fornell \& Larcker, 1981). These ranged from .71 to .84 , all greater than the acceptable minimum value of .70 for these measures (Bagozzi et al., 1991).

Following an approach recommended by Bagozzi et al. (1991), nested models of the correlations among pairs of variables were compared to further test discriminant validity. A chi-square difference test determined whether the constrained and unconstrained pairs of constructs significantly differed (Anderson \& Gerbing, 1988). For all pairs, the unconstrained model, less one degree of freedom, indicated a chi-square of at least 3.84 lower than that of the constrained model, indicating discriminant validities for all pairs (Anderson \& Gerbing, 1988; Farrell, 2010).

Ordered continuous variables provided measures for the independent variables of age and tenure. All independent variables were centered to minimize multicollinearity (Cohen, 1988; Edwards, 1957). Collinearity diagnostics were performed for the independent variables. All variance inflation factor (VIF) measures were less than two, the cutoff considered to be the acceptable standard.

Table I presents descriptions of the items and scales included in these analyses. Table II presents the correlations among independent variables.

Multinomial logistic regression tested the hypotheses for those who had selected one of the four options and those who rejected all options. Multinomial logistic regression is recommended for the analysis of data in which the dependent variable is ordinal, the multiple independent variables are either categorical or continuous, and their relationships are best represented by model-fitting procedures (Garson, 2009). Logistic regression, and, by extension, multinomial logistic regression, makes no assumptions about normality, linearity, or equal variances within each group for independent variables in the log function (Tabachnick \& Fidell, 1996, p. 575 ). Because of these relaxations of assumptions in log functions, the procedure is relatively robust when analyzing groups with unequal sample sizes (Garson, 2009).

This procedure tested the hypotheses for those who chose the retirement-eligible incentive, the paid-retirement furlough, the reduced-benefit retirement, and the lumpsum payment versus those who had accepted none of the options, and chose to remain active employees of the organization. Active employees, those who had accepted none of the options, constituted the primary reference group for the tests of the hypotheses. Although not associated specifically with the hypotheses, differences between pairs of groups other than those involving the active employee group also were of interest in this study. To assess all comparisons among all levels of the 


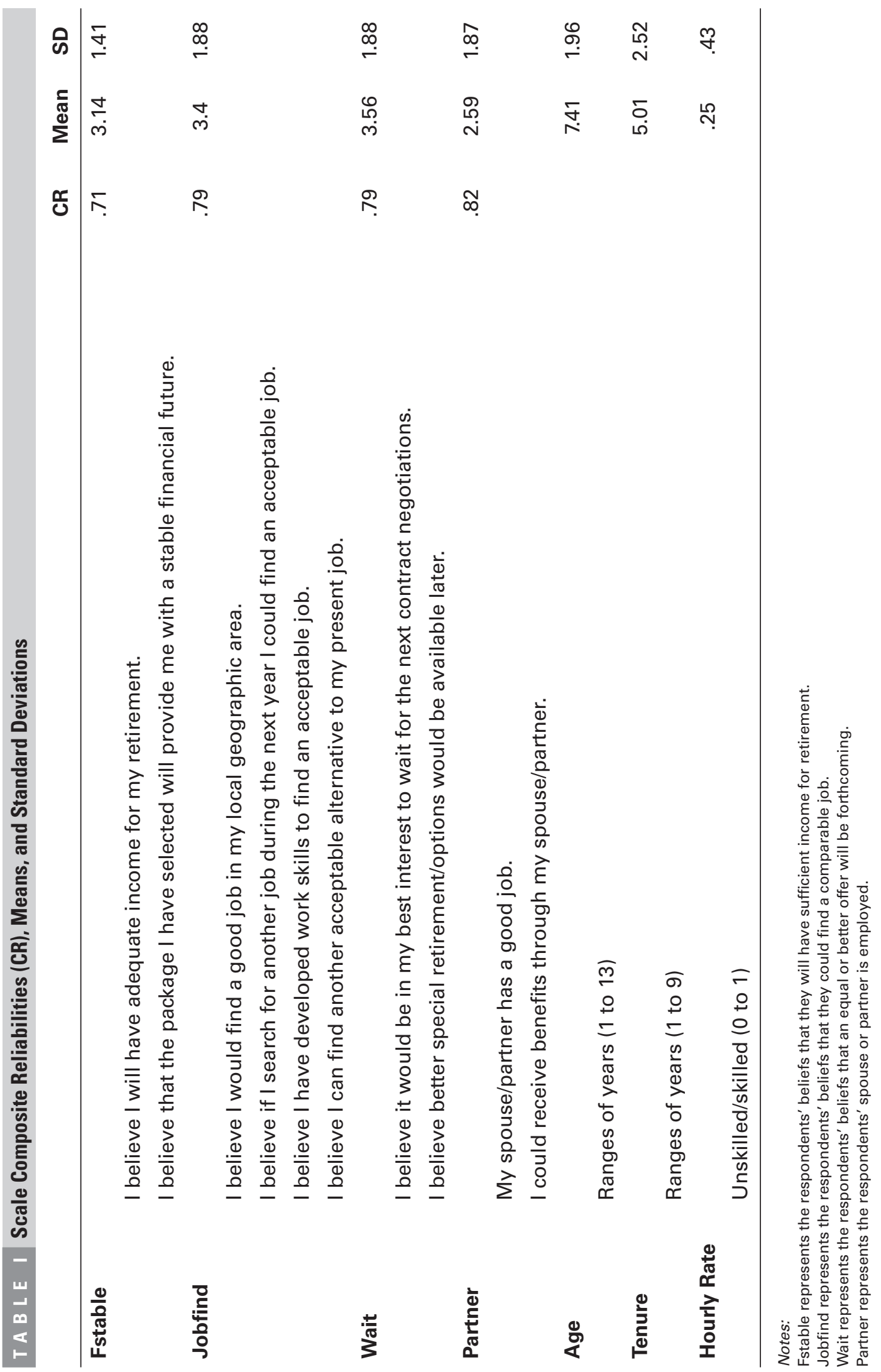




\section{T A B L E I I Pearson Correlations Among Independent Variables}

\begin{tabular}{|c|c|c|c|c|c|c|c|}
\hline & & 1 & 2 & 3 & 4 & 5 & 6 \\
\hline 1 & Fstable & & & & & & \\
\hline 2 & Jobfind & $.310 * *$ & & & & & \\
\hline 3 & Wait & $-.140 * *$ & $-.115^{*}$ & & & & \\
\hline 4 & Partner & $.126^{*}$ & $.144 * *$ & .003 & & & \\
\hline 5 & Age & $.133^{* *}$ & -.040 & .030 & $.176 * *$ & & \\
\hline 6 & Tenure & $.271 * *$ & .033 & -.071 & $-.153^{* *}$ & $.671 * *$ & \\
\hline 7 & Hourly Rate & $-.103^{*}$ & $.128 * * *$ & .005 & $-.122 *$ & $.210 * *$ & $.101 *$ \\
\hline
\end{tabular}

dependent variable, the reference group was varied during four runs of the model.

Multinomial regression requires minimum numbers of responses for each independent variable to minimize Type I errors (Garson, 2009). At least five cases are required for each independent variable within each dependent variable category. Tabachnick and Fidell (2001) suggest a heuristic for testing $b$ coefficients in multinomial logistic regression: where $m=$ number of independent variables, $N$ must be greater than $104+m$. Other heuristics require at least 20 cases for each independent variable or 40 times the number of independent variables for the overall sample size (Garson, 2009). Our sample fulfilled these heuristics, having 324 cases, seven independent variables, and at least 40 cases for each of the five dependent variable categories.

\section{Results}

The Akaike's information criterion (AIC) and the Bayesian information criterion (BIC) indicated that the model that included the independent variables provided a significantly better fit to the data when compared to the model including the intercept only. Similarly, the Likelihood Ratio Tests were significant, $\chi^{2}(28, N=324)=551.88, p<.001$, indicating that the model containing the independent variables significantly improved explanation of the relationships in the data. Cox and Snell, Nagelkerke, and McFadden faux $R^{2}$ statistics were $.82, .87$, and .58 , respectively.

The classification hit rate indicated that 74.6 percent of the cases were correctly classified. The proportional-by-chance-accuracy rate for the classification was 34 percent. The latter percentage represents the accuracy rate attributable to chance multiplied by 1.25 . It is considered to be the minimum predictive percentage for meaningful classification results (Garson, 2009).

\section{Active Employee Group as Referent}

Individuals in the retirement-eligible incentive group were more confident that they would have adequate retirement income $(p<$ $.01)$, were less likely to wait $(p<.001)$, were older $(p<.001)$, had more tenure $(p<.001)$, and were less likely to have financial support from a partner $(p<.01)$ than were those who rejected the offer and chose to stay.

Individuals in the paid-retirement furlough group, compared with those in the active employee group, were more likely to believe they would have adequate retirement income $(p<.01)$, were less likely to believe that waiting was worthwhile $(p<.001)$, had more tenure $(p<.001)$, and held lower hourly wage jobs $(p<.01)$. 
Compared to those in the active employee group, individuals who chose the reducedbenefit retirement option were more likely to state they could find alternate employment $(p$ $<$.001), were less likely to believe that waiting would be beneficial $(p<.001)$, and were older $(p<.001)$.

Employees who accepted the lump-sum payment, compared to active employees, were more likely to believe they could find an alternative job $(p<.001)$, disagreed that there was a benefit to waiting $(p<.001)$, were younger $(p<.05)$, had less tenure $(p<$ $.05)$, and were employed in lower-wage jobs $(p=.001)$.

\section{Retirement-Eligible Incentive Group as Referent}

Employees from the paid-retirement furlough group were younger $(p=.001)$, had less tenure $(p<.01)$, and had lower pay $(p<.05)$ than those from the retirement-eligible incentive category.

Compared to those in the retirementeligible incentive group, respondents in the lump-sum payment group had less confidence about a stable financial future $(p=.01)$, were younger $(p<.001)$, had less tenure $(p<$ $.001)$, held lower-wage jobs $(p<.05)$, and had greater partner support $(p<.05)$.

Compared to the retirement-eligible incentive employees, the reduced-benefit retirement group respondents were more likely to see benefits in waiting $(p<.01)$, be younger $(p<.01)$, and have less tenure $(p<$ $.001)$.

\section{Paid-Retirement Furlough Group as Referent}

Individuals in the reduced-benefit retirement group were more likely to believe it was better to wait $(p<.05)$, were older $(p=.001)$, had less tenure $(p<.001)$, and held higher-wage jobs $(p<.05)$ than those in the paid-retirement furlough group.

Respondents who accepted a lump-sum payment were more concerned about a stable financial future $(p<.01)$ and reported

less tenure $(p<.001)$ than those in the paidretirement furlough group.

\section{Reduced-Benefit Retirement Group as Referent}

When compared to reduced-benefit retirement as the reference category, those who chose the lump-sum payment were less likely to see the benefit of waiting ( $p<.001)$, were younger $(p<.001)$, had less tenure $(p<.01)$, and held lower-wage jobs $(p<.05)$.

Tables III through VI present the results from the multinomial logistic regressions, including the $B$ coefficients, standard errors, odds ratios, and confidence intervals for the four models.

By understanding

\section{Discussion}

In our opinion, the main contribution this study makes to severance options research is the comparisons of the characteristics of those who accepted one of the options and those who rejected all offers. Moreover, our study allowed the comparisons of individuals who accepted four distinctly different alternatives, two of them not resulting in full retirement. By understanding the similarities and differences among the individuals who chose one of the severance options and those individuals who rejected all options, organizations may be able to predict and control the talent pool without resorting to forced layoffs. The following discussion addresses similarities and differences among these groups.

\section{Stable Financial Future}

Hypothesis 1 was partially supported. Individuals in both the retirement-eligible incentive and the paid-retirement furlough groups were more likely to believe they would have a stable financial future than were the 
T A B L E I I I Multinomial Logistic Regression for Variables on Choices: Active Employee as Referent

$95 \%$ Confidence

Interval for OR

\begin{tabular}{|c|c|c|c|c|c|c|}
\hline & & $B$ & SE & OR & Lower & Upper \\
\hline \multirow{8}{*}{$\begin{array}{l}\text { Retirement- } \\
\text { Eligible } \\
\text { Incentive }\end{array}$} & Intercept & $-7.97 * * *$ & 1.49 & & & \\
\hline & Fstable & $.67 * *$ & .26 & 1.97 & 1.18 & 3.29 \\
\hline & Jobfind & .38 & .25 & 1.47 & .90 & 2.41 \\
\hline & Wait & $-1.18 * * *$ & .21 & .30 & .20 & .46 \\
\hline & Age & $1.77^{* * *}$ & .41 & 5.91 & 2.67 & 13.08 \\
\hline & Tenure & $2.01 * * *$ & .35 & 7.53 & 3.79 & 14.97 \\
\hline & Hourly Rate & -.16 & .77 & .85 & .19 & 3.84 \\
\hline & Partner & $-.55^{* *}$ & .21 & .57 & .38 & .86 \\
\hline \multirow{8}{*}{$\begin{array}{l}\text { Paid- } \\
\text { Retirement } \\
\text { Furlough }\end{array}$} & Intercept & $-1.99 * * *$ & .43 & & & \\
\hline & Fstable & $.63^{* *}$ & .24 & 1.89 & 1.19 & 3.01 \\
\hline & Jobfind & .31 & .20 & 1.36 & .92 & 2.02 \\
\hline & Wait & $-.94 * * *$ & .17 & .39 & .28 & .55 \\
\hline & Age & -.39 & .28 & .67 & .39 & 1.16 \\
\hline & Tenure & $1.08 * * *$ & .21 & 2.95 & 1.98 & 4.41 \\
\hline & Hourly Rate & $-2.50 * *$ & .87 & .08 & .02 & .45 \\
\hline & Partner & -.31 & .17 & .73 & .52 & 1.03 \\
\hline \multirow{8}{*}{$\begin{array}{l}\text { Lump-Sum } \\
\text { Payment }\end{array}$} & Intercept & $-3.40 * * *$ & .73 & & & \\
\hline & Fstable & -.18 & .24 & .83 & .52 & 1.32 \\
\hline & Jobfind & $.67 * * *$ & .18 & 1.96 & 1.39 & 2.76 \\
\hline & Wait & $-1.41 * * *$ & .22 & .24 & .16 & .37 \\
\hline & Age & $-.36^{*}$ & .18 & .70 & .49 & .99 \\
\hline & Tenure & $-.76^{*}$ & .30 & .46 & .26 & .84 \\
\hline & Hourly Rate & $-2.43 * *$ & .76 & .09 & .02 & .39 \\
\hline & Partner & -.01 & .12 & .99 & .78 & 1.25 \\
\hline \multirow{8}{*}{$\begin{array}{l}\text { Reduced- } \\
\text { Benefit } \\
\text { Retirement }\end{array}$} & Intercept & $-1.02 * * *$ & .28 & & & \\
\hline & Fstable & .33 & .18 & 1.40 & .98 & 2.00 \\
\hline & Jobfind & $.51 * *$ & .16 & 1.68 & 1.24 & 2.27 \\
\hline & Wait & $-.61 * * *$ & .14 & .54 & .41 & .71 \\
\hline & Age & $.59 * * *$ & .17 & 1.81 & 1.31 & 2.51 \\
\hline & Tenure & .16 & .12 & 1.17 & .94 & 1.47 \\
\hline & Hourly Rate & -.44 & .46 & .64 & .26 & 1.57 \\
\hline & Partner & -.16 & .13 & .85 & .66 & 1.08 \\
\hline
\end{tabular}

${ }^{*} p<.05,{ }^{* *} p<.01,{ }^{* * *} p<.001$. 


\begin{tabular}{|c|c|c|c|c|c|c|}
\hline \multirow[t]{3}{*}{$\begin{array}{lr}\text { T A B L E I V } & \text { Mul } \\
& \text { Refe }\end{array}$} & \multicolumn{6}{|c|}{$\begin{array}{l}\text { Multinomial Logistic Regression for Variables on Choices: Retirement-Eligible Incentive as } \\
\text { Referent }\end{array}$} \\
\hline & & \multirow[b]{2}{*}{$B$} & \multirow[b]{2}{*}{ SE } & \multirow[b]{2}{*}{ OR } & \multicolumn{2}{|c|}{$\begin{array}{l}95 \% \text { Confidence } \\
\text { Interval for OR }\end{array}$} \\
\hline & & & & & Lower & Upper \\
\hline \multirow{8}{*}{$\begin{array}{l}\text { Paid-Retirement } \\
\text { Furlough }\end{array}$} & Intercept & $5.98 * * *$ & 1.50 & & & \\
\hline & Fstable & -.04 & .23 & .96 & .61 & 1.50 \\
\hline & Jobfind & -.07 & .24 & .93 & .58 & 1.47 \\
\hline & Wait & .24 & .19 & 1.28 & .88 & 1.86 \\
\hline & Age & $-2.17 * * *$ & .44 & .11 & .05 & .27 \\
\hline & Tenure & $-.93 * *$ & .35 & .39 & .20 & .78 \\
\hline & Hourly Rate & $-2.34 *$ & .95 & .10 & .02 & .62 \\
\hline & Partner & .24 & .20 & 1.28 & .86 & 1.91 \\
\hline \multirow{8}{*}{$\begin{array}{l}\text { Lump-Sum } \\
\text { Payment }\end{array}$} & Intercept & $4.56^{* *}$ & 1.64 & & & \\
\hline & Fstable & $-.86 * *$ & .33 & .42 & .22 & .81 \\
\hline & Jobfind & .28 & .29 & 1.33 & .76 & 2.32 \\
\hline & Wait & -.22 & .29 & .80 & .45 & 1.40 \\
\hline & Age & $-2.13^{* * *}$ & .44 & .12 & .05 & .28 \\
\hline & Tenure & $-2.78 * * *$ & .46 & .06 & .03 & .15 \\
\hline & Hourly Rate & $-2.26^{*}$ & 1.04 & .10 & .01 & .79 \\
\hline & Partner & $.54 *$ & .23 & 1.73 & 1.10 & 2.72 \\
\hline \multirow{8}{*}{$\begin{array}{l}\text { Reduced-Benefit } \\
\text { Retirement }\end{array}$} & Intercept & $6.94 * * *$ & 1.49 & & & \\
\hline & Fstable & -.34 & .24 & .71 & .44 & 1.14 \\
\hline & Jobfind & .12 & .24 & 1.14 & .71 & 1.83 \\
\hline & Wait & $.57 * *$ & .20 & 1.78 & 1.21 & 2.64 \\
\hline & Age & $-1.18 * *$ & .40 & .31 & .14 & .67 \\
\hline & Tenure & $-1.85^{* * *}$ & .35 & .16 & .08 & .31 \\
\hline & Hourly Rate & -.28 & .75 & .75 & .18 & 3.25 \\
\hline & Partner & .39 & .21 & 1.48 & .99 & 2.22 \\
\hline
\end{tabular}

${ }^{*} p<.05,{ }^{* *} p<.01,{ }^{* * *} p<.001$.

individuals who rejected the options. These results are explainable by the fact that individuals in both these groups had already reached or were close to receiving full retirement benefits.

Other findings indicated that individuals in the lump-sum payment group were less likely to believe the package would provide a stable financial future than were those in the retirement-eligible incentive and paidretirement furlough groups. A possible explanation for these findings might be that for individuals in the lump-sum payment group, the lump-sum payment represented more of a short-term fix, rather than a guarantee of a stable financial future.

\section{Job Find}

Hypothesis 2, relating to the availability of a comparable job, was partially supported. Compared to the individuals in the active employee group, those who chose the reduced-benefit retirement and lump-sum 


\begin{tabular}{|c|c|c|c|c|c|c|}
\hline & & \multirow[b]{2}{*}{$B$} & \multirow[b]{2}{*}{ SE } & \multirow[b]{2}{*}{ OR } & \multicolumn{2}{|c|}{$\begin{array}{l}\text { 95\% Confidence } \\
\text { Interval for OR }\end{array}$} \\
\hline & & & & & Lower & Upper \\
\hline \multirow{8}{*}{$\begin{array}{l}\text { Lump-Sum } \\
\text { Payment }\end{array}$} & Intercept & -1.41 & .82 & & & \\
\hline & Fstable & $-.821^{*}$ & .31 & .44 & .24 & .81 \\
\hline & Jobfind & .36 & .24 & 1.44 & .91 & 2.28 \\
\hline & Wait & -.47 & .25 & .62 & .38 & 1.02 \\
\hline & Age & .03 & .31 & 1.04 & .56 & 1.91 \\
\hline & Tenure & $-1.85^{* * *}$ & .35 & .16 & .08 & .31 \\
\hline & Hourly Rate & .07 & 1.09 & 1.08 & .13 & 9.20 \\
\hline & Partner & .29 & .20 & 1.35 & .92 & 1.99 \\
\hline \multirow{8}{*}{$\begin{array}{l}\text { Reduced-Benefit } \\
\text { Retirement }\end{array}$} & Intercept & .96 & .47 & & & \\
\hline & Fstable & -.30 & .22 & .74 & .48 & 1.14 \\
\hline & Jobfind & .20 & .20 & 1.23 & .83 & 1.82 \\
\hline & Wait & $.33^{*}$ & .16 & 1.39 & 1.01 & 1.92 \\
\hline & Age & $.99 * *$ & .29 & 2.70 & 1.53 & 4.77 \\
\hline & Tenure & $-.92 * * *$ & .20 & .40 & .27 & .59 \\
\hline & Hourly Rate & $2.06 * *$ & .85 & 7.86 & 1.47 & 41.88 \\
\hline & Partner & .14 & .17 & 1.16 & .82 & 1.62 \\
\hline
\end{tabular}

${ }^{*} p<.05,{ }^{* *} p<.01,{ }^{* * *} p<.001$.

T A B L E V I Multinomial Logistic Regression for Variables on Choices: Reduced Benefit Retirement as Referent
95\% Confidence

Interval for OR

\begin{tabular}{llccccc} 
& & $\boldsymbol{B}$ & SE & OR & Lower & Upper \\
\hline Lump-Sum Payment & Intercept & $-2.38^{* *}$ & .75 & & & \\
& Fstable & -.51 & .27 & .60 & .35 & 1.01 \\
& Jobfind & .15 & .20 & 1.17 & .79 & 1.73 \\
& Wait & $-.80^{* * *}$ & .23 & .45 & .28 & .70 \\
& Age & $-.95^{* * *}$ & .23 & .38 & .25 & .60 \\
& Tenure & $-.92^{* *}$ & .31 & .40 & .22 & .73 \\
& Hourly Rate & $-1.98^{*}$ & .81 & .14 & .03 & .68 \\
& Partner & .15 & .15 & 1.17 & .86 & 1.58 \\
\hline
\end{tabular}

${ }^{*} p<.05,{ }^{* *} p<.01,{ }^{* * *} p<.001$. 
payment options were more likely to believe that they could find comparable employment. This was as predicted. In our reasoning, both of these groups faced difficult economic decisions. Those in the reduced-benefit group lacked the combination of age and tenure to earn full retirement benefits and faced potential layoff. Those in the lump-sum group also did not have sufficient age and tenure to retire and faced a greater likelihood of layoff. The packages offered to the individuals in these two groups would not outweigh the costs of giving up a job with high wages and good benefits unless they believed they could find comparable employment elsewhere.

Hypothesis 2 was not supported with respect to the paid-retirement furlough group and the retirement-eligible incentive group. A possible explanation for these results is that those individuals who took the respective packages believed that they would not need to find a comparable job because the firm offered generous retirement packages.

\section{Wait}

As hypothesized (Hypothesis 3), those who accepted any of the four options were more likely to believe that a better offer was not forthcoming when compared to the active employee group. In findings from the regressions comparing groups that accepted the offers, individuals in the reduced-benefit retirement group were most likely to believe that a better offer was forthcoming when compared to the individuals in the retirement-eligible incentive, paid-retirement furlough, and lump-sum payment groups.

\section{Age}

Hypothesis 4a was partially supported. Individuals in the retirement-eligible incentive group were older than the individuals in the active employee group. The opportunity to receive a bonus and full retirement was available to only older individuals. In our opinion, the retirement-eligible incentive added the needed financial incentive to motivate retirement augmenting this group's image of a stable financial future.
Hypothesis 4b was supported with respect to the lump-sum payment group, which included the individuals with the lowest average age of all groups. Opposite to our predictions, age was positively associated with the decision to accept the reduced-benefit retirement option. We believe this result is related to the requirement that this group be at least 50 years old. As such, they tended to be older than those who rejected the offer. In addition, as individuals age, jobs requiring manual labor and long hours become less attractive.

\section{Tenure}

Hypothesis 5a was supported. For those individuals who accepted the retirement-eligible incentive and the paid-retirement furlough, organizational tenure was higher than that of those who rejected all offers.

Hypothesis 5b was partially supported. The individuals who chose the lump-sum payment had less organizational tenure than those who rejected the offers. Compared to the active employee group, these individuals had fewer investments in the organization, such as pension benefits.

\section{Hourly Rate}

Hourly rate was negatively associated with the probability that an individual would accept the lump-sum payment option, confirming Hypothesis 6b. Opposite to our prediction (Hypothesis 6a), the individuals who accepted the paid-retirement furlough also had lower hourly rates than those who rejected the offers. In this work situation, lower pay was associated with assembly-line jobs. Reasonably, these jobs require more manual labor and unappealing working conditions, thereby making them less attractive than higher-paid skilled jobs.

\section{Working Partner}

A working partner was predicted to affect the choice to accept or reject an offer contingent upon the life circumstances of the employees. Partially supporting Hypothesis 7a, individuals in the retirement-eligible incentive group were less likely to have a working partner 
than those in the active employee group. Research (e.g., Hallberg \& Eklöf, 2010; Hogarth, 1988; Kim \& Feldman, 1998; Väre, 2006) has shown that retirement is often a coordinated activity between partners, and, in this case, the retirement bonus might have only motivated those who did not have significant coordination issues with a partner to leave.

Among nonhypothesized findings, those employees who chose the lump-sum payment, the youngest group, were more likely to have a working partner than were those in the retirement-eligible incentive group. Because younger individuals are more likely to have family and financial responsibilities (Adams \& Beerh, 1998), we interpret the choice of the lump-sum payment to be related to the presence of the

The array of

severance packages financial buffer of another income in the household.

compared in

this study offers

\section{Implications for Practice}

flexibility to

organizations

pursuing a

downsizing strategy.

Our findings will help organizations to manage their talent bases (Cascio \& Wynn, 2004). By understanding the demographic, economic, and psychographic characteristics that differentiate individuals who reject and accept an array of packages, the organization can proactively structure its severance options. By having an array of options, organizations can predict and create the talent mix that they require for the future. Historically, downsizing has entailed either buying out senior employees or laying off junior employees. The array of severance packages compared in this study offers flexibility to organizations pursuing a downsizing strategy.

We believe the unique implications from our study are related to the decisions of the reduced-benefit retirement and the lump-sum payment groups. These are the individuals who have their expectations of retirement and a stable financial future most disrupted. Not only were they presented with the options with the least promise of future stability, but they also faced the greatest possibility of permanent layoff. For both of these groups, the beliefs that they would be able to replace their current jobs with comparable ones were critical to their decisions to accept the offer. Because of relatively high wage rates in this industry, comparable paying jobs for these manufacturing employees are rare. If organizations realistically expect these less tenured individuals to leave, they must prepare them for jobs requiring more sophisticated skills and offer job-placement services. Offering training and education programs to develop skills (e.g., technological, managerial, and entrepreneurial) that would transfer to other industries would increase the chances that these individuals would accept an offer. As added bonuses for organizations, these skills and abilities would create a workforce proficient in the newest technologies and entrepreneurial techniques.

From our results, the message to organizations anticipating downsizing is to be consistent. Individuals who accepted any of the options were less likely to believe that better offers were forthcoming. In this industry, many employees have been through its economic cycles and have experienced downsizings in the past. The expectation that more or better offers would be forthcoming is part of the corporate culture. Regardless, organizations should pursue a strategy of describing the current offer, as well as the immediate consequences if severance targets are not met. Short-term consequences for those who do not accept the package should be described before the offers are made and, of course, implemented, if warranted.

In general, the results of this study pertaining to the full retirement options replicate those of previous research on the effects of age, tenure, and financial stability. Because much of this research was conducted in the 1980 s and 1990s, our results infer that individual decisions to retire are affected by similar factors today. Decisions to accept any of the options were generally made consistent with the individual's image of maintaining a certain standard of living (Feldman, 1994).

\section{Research Limitations}

We studied one organization, and our findings may not be generalizable to other 
organizations. Then again, multiple departments and facilities in the pilot cities of the organization were included in the study. Accomplishing multi-organizational research may not be feasible because organizations downsize in unique ways, through different programs and incentives.

From a measurement perspective, most scales were developed from fewer than the recommended four to six items. The study was funded by the organization and its union, with the goal of collecting significant amounts of information from the survey. The sponsors limited the number of items on the survey. They also wanted specific information that often did not correspond with previously validated research scales. Despite these constraints, all variables met minimal standards from a measurement model perspective.

We acknowledge that there may be a problem associated with a 19 percent response rate. On the other hand, this study represented a unique opportunity to obtain data from an organization that was intended to be used for guidance for upcoming severance offers. The data met standards that have historically been utilized to assess nonresponse bias.

Finally, our study is limited to one organization located in the United States. In the United States, when an employee rejects a severance package, he/she significantly increases the risk of his/her layoff. However, this is not true in all countries. Governments in some countries can block layoffs not previously approved by governmental agencies (e.g., the Netherlands, Japan, Korea, and China) (Dowling, 2009). In addition, the European Union requires consultation with employees and additional obligations, such as retraining beyond severance compensation (Dowling, 2009). Without the threat of layoff or with the presence of social safety nets, workers in the United States might choose differently.

\section{Suggestions for Future Research}

Recently, severance options have been similar across organizations within an industry. Organizations in the same industry offering similar arrays of packages might provide opportunities for multi-organizational research. Certainly, larger sample sizes would allow the number of independent variables to be increased, as well as add to the statistical power of the analyses.

Future studies might compare different categories of employees from the same organization's workforce. Differences among blue-collar, white-collar, technical, clerical, and professional workers and their reactions to separation packages have not been identified. Also, no research has compared the influence of defined-benefit plans versus defined-contributions plans on employee willingness to accept a severance offer. By expanding the scope of research in this area, organizations may be provided with better guidance about how to achieve optimal employee mixes in a downsizing situation.

Furthermore, cognitive dissonance (Festinger, 1964) may have affected our results. Individuals who accepted or rejected packages likely had conflicting thoughts and beliefs about what was a life-changing decision. Future research should consider longitudinal research that would investigate pre- and post-decision cognitive processes.

\section{Authors' Notes}

We wish to thank Robert Steel and three anonymous reviewers for their invaluable feedback on this manuscript.

Order of authorship was determined randomly. 
KAREN STRANDHOLM, PhD, JD, is an associate professor of strategic management at the University of Michigan-Dearborn. She received a PhD in strategy from Indiana University. Her current research interests include strategy and the environment and strategy and market orientation. She also does pedagogy research. She has published in refereed strategy and business journals and proceedings, including the Journal of Business Research, Entrepreneurship Theory and Practice, and the Journal of Education for Business, among others.

KIM SCHATZEL, after more than 20 years of corporate business experience, joined the faculty of the University of Michigan-Dearborn in 2000, where she served as dean of the College of Business from 2008 to 2012, when she was appointed provost and vice president at Eastern Michigan University. Her teaching interests include marketing research, marketing strategy, new product development, new venture creation, quantitative methods, high-technology marketing, and technology management. She received a doctorate in business administration from Michigan State University and a BS in economics and biology from Washington University in St. Louis.

THOMAS CALLAHAN is an associate professor of management at the University of Michigan-Dearborn. He received his PhD in organizational behavior from Michigan State University. He is the senior research consultant for Amplitude Research, Inc. His recent research interests have included the topics of leadership, turnover, stopouts in higher education, decision making, and the efficacy of development programs for disadvantaged businesses.

\section{References}

Adams, G. A., \& Beerh, T. A. (1998). Turnover and retirement: A comparison of their similarities and differences. Personnel Psychology, 51, 643-665.

Anderson, J. C., \& Gerbing, D. W. (1988). Structural equation modeling in practice: A review and recommended two-step approach. Psychological Bulletin, 103, 411-423.

Appelbaum, S. H., Patton, E., \& Shapiro, B.T. (2003). The early retirement incentive program: A downsizing strategy. Journal of European IndustrialTraining, 27, 22-35.

Armstrong, J. S., \& Overton, T. S. (1977). Estimating nonresponse bias in mail surveys. Journal of Marketing Research, 16, 396-402.

Bagozzi, R., Yi, Y., \& Phillips, L. (1991). Assessing construct validity in organizational research. Administrative Science Quarterly, 36, 421-458.

Bahrami, B. (1999). Determinants of faculty early retirement decisions. Journal of Economics, 25, 285-306.
Beach, L. R. (1993). Broadening the definition of decision making: The role of prochoice screening of options. Organizational and Human Decision Processes, 67, 222-228.

Beach, L. R., \& Frederickson, J. R. (1989). Image theory: An alternative description of audit decisions. Accounting Organizations and Society, 14, 101-112.

Becker, H. S. (1960). Notes on the concept of commitment. American Journal of Sociology, 33, 33-42.

Bluedorn, A. (1982). The theories of turnover: Causes, effects and meaning. In S. Bacharach (Ed.). Research in the sociology of organizations (Vol. 1, pp. 75-128). Greenwich, CT: JAI Press.

Bretz, R. D., Boudreau, J. W., \& Judge, T. A. (1994). Job search behavior of employed managers. Personnel Psychology, 47, 275-301.

Brockner, J. (1988). The effects of work layoffs on survivors: Research theory and practice. Research in Organizational Behavior, 10, 213-255.

Brockner, J. (1992). Managing the effects of layoffs on survivors. California Management Review, 34(2), 9-28. 
Broughm, R., \& Walsh, D. (2007). Image theory, goal incompatibility, and retirement intent. International Journal of Aging and Human Development, 64, 203-229.

Cascio, W. (2002). Strategies for responsible restructuring. Academy of Management Executive, 16(3), 80-91.

Cascio, W., \& Wynn, P. (2004). Managing a downsizing process. Human Resource Management, 43, 425-436.

Cascio, W. F., Young, C. E., \& Morris, J. R. (1997). Financial consequences of employment: Change decisions in major U.S. corporations. Academy of Management Journal, 40, 1175-1189.

Cho, V., \& Huang, X. (2012). Professional commitment, organizational commitment, and the intention to leave for professional advancement: An empirical study on IT professionals. Information Technology \& People, 25(1), 31-54.

Cohen, J. (1988). Statistical power analysis for the behavioral sciences (2nd ed.). Philadelphia, PA:Taylor \& Francis.

Datta, D., Guthrie, J., Basuil, D., \& Pandey, A. (2010). Causes and effects of employee downsizing: $A$ review and synthesis. Journal of Management, 36, 281-348.

Devine, D., Reay, T., Stainton, L., \& Collins-Nakai, R. (2003). Downsizing outcomes: Better a victim than a survivor? Human Resource Management, 42, 109-124.

Dowling, D. (2009). Layoffs outside the U.S. Employment Benefit Plan Review, 63(9), 15-16.

Edwards, A. L. (1957). Techniques of attitude scale construction. New York, NY: Appleton-Century-Crofts.

Espahbodi, R., John, T. A., \& Vasudevan, G. (2000). The effects of downsizing on operating performance. Review of Quantitative Finance and Accounting, 15, 107-126.

Farrell, A. M. (2010). Insufficient discriminant validity: A comment on Bove, Pervan, Beatty, and Shiu (2009). Journal of Business Research, 63, 324-327.

Feldman, D. C. (1994). The decision to retire early: A review and conceptualization. Academy of Management Review, 19, 285-311.

Feldman, D. C., \& Turnley, W. H. (1995). Factors influencing intentions to retire: An empirical test of theoretical propositions. Management Research News, 18(7), 28-46.

Festinger, L. (1964). Conflict, decision, and dissonance. Stanford, CA: Stanford University Press.
Fields, G. S., \& Mitchell, O. S. (1984). Economic determinants of the optimal retirement age: An empirical investigation. Journal of Human Relations, 19, 245-262.

Fornell, C., \& Larcker, D. F. (1981). Evaluating structural equation models with unobservable variables and measurement error. Journal of Marketing Research, $18,39-50$.

Garson, G. D. (2009). Logistic regression. Retrieved from http://faculty.chass.ncsu.edu/garson/pa765 /statnote.htm

Gowan, M. A. (1998). A preliminary investigation of factors affecting appraisal of the decision to take early retirement. Journal of Employment Counseling, 35(3), 124-140.

Griffeth, R. W., Hom, P. W., \& Gaertner, S. (2000). A meta-analysis of antecedents and correlates of employee turnover: Update, moderator tests, and research implications for the next millennium. Journal of Management, 26, 463-488.

Guthrie, J. P., \& Datta, D. K. (2008). Dumb and dumber: The impact of downsizing on firm performance as moderated by industry conditions. Organization Science, 19, 108-123.

Hallberg, D., \& Eklöf, M. (2010). Do buy-outs of older workers matter? Estimating retirement behavior with special early retirement offers. International Journal of Manpower, 31, 337-359.

Hardy, M. A., \& Hazelrigg, L. (1999). A multilevel model of early retirement decisions among autoworkers in plants with different futures. Research on Aging, 21, 275-303.

Hogarth, J. M. (1988). Accepting an early retirement bonus: An empirical study. Journal of Human Resources, 23, 21-33.

Iverson, R. D., \& Buttigieg, D. M. (1999). Affective, normative and continuance commitment: Can the 'right kind' of commitment be managed? Journal of Management Studies, 36, 307-333.

Iverson, R. D., \& Zatzick. C. (2011). The effects of downsizing on labor productivity: The value of showing consideration for employees' moral and welfare in high-performance work systems. Human Resource Management, 50, 29-44.

Karoly, L. A., \& Rogowski, J. A. (1994). The effect of access to post-retirement health insurance on the decision to retire early. Industrial \& Labor Relations Review, 48, 103-124.

Kim, S., \& Feldman, D. C. (1998). Healthy, wealthy, or wise: Predicting actual acceptances of early retirement incentive at three points in time. Personnel Psychology, 51, 623-642. 
Koeber, C., \& Wright, D. W. (2006). Gender differences in the reemployment status of displaced workers human capital as signals that mitigate effects of bias. Journal of Socio-Economics, 35, 780-796.

Lee, T. W., \& Mitchell, T. R. (1994). An alternative approach:The unfolding model of voluntary turnover. Academy of Management Review, 19, 51-89.

Lewin, J. E. (2003). An empirical investigation of the effects of downsizing on buyer-seller relationships. Journal of Business Research, 56, 283-293.

Lewin, J. E. (2009). Business customers'satisfaction: What happens when suppliers downsize? Industrial Marketing Management, 38, 283-299.

Lindner, J. R., Murphy, T. H., \& Briers, G. E. (2001). Handling nonresponse in social science research. Journal of Agricultural Education, 42(4), 43-53.

Marks, M. (2006). Workplace recovery after mergers, acquisitions, and downsizings: Facilitating individual adaptation to major organizational transitions. Organizational Dynamics, 35, 384-399.

Mathieu, J. E., \& Zajac, D. M. (1990). A review and meta-analysis of the antecedents, correlates, and consequences of organizational commitment. Psychological Bulletin, 108, 171-194.

Mehay, S., \& Hogan, P. (1998). The effect of separation bonuses on voluntary quits: Evidence from the military's downsizing. Southern Economic Journal, 65, 127-139.

Mishra, K., Spreitzer, G., \& Mishra, A. (1998). Preserving employee morale during downsizing. Sloan Management Review, 39(2), 83-95.

Mobley, W. H., Griffeth, R. W., Hand, H. H., \& Meglino, B. M. (1979). A review and conceptual analysis of the employee turnover process. Psychological Bulletin, 86, 493-522.

Muñoz-Bullón, F., \& Sánchez-Bueno, M .J. (2010). Downsizing implementation and financial performance. Management Decision, 48, 1181-1197.

Palmon, O., Sun, H., \&Tang, A. P. (1997). Layoff announcements: Stock market impact and financial performance. Financial Management, 26(3), 54-68.

Pencavel, J. (2001). The response of employees to severance incentives:The University of California's faculty, 1991-1994. Journal of Human Resources, $36,58-84$

Procon.org. (2009). Average hourly compensation 2006 (U.S. wages and benefits). Retrieved from http://bigthreeauto.procon.org/view.additional -resource.php?resourcelD $=2050$

Smith, D. R., Holtom, B. C., \& Mitchell, T. C. (2011). Enhancing precision in the prediction of voluntary turnover and retirement. Journal of Vocational Behavior, 79, 290-302.

Steel, R. P., \& Griffeth, R. W. (1989). The elusive relationship between perceived employment opportunity and turnover behavior: A methodological or conceptual artifact? Journal of Applied Psychology, 74, 846-854.

Steers, R. M. (1977). Antecedents and outcomes of organizational commitment. Administrative Science Quarterly, 22, 46-56.

Tabachnick, B., \& Fidell, L. (1996). Using multivariate statistics (3rd ed.). New York, NY: HarperCollins.

Trevor, C., \& Nyberg, A. J. (2008). Keeping your headcount when all about you are losing theirs: Downsizing, voluntary turnover rates, and the moderating role of HR practices. Academy of Management Journal, 51, 259-276.

Van Breukelen, W., Van Der Vlist, R., \& Steensma, H. (2004). Voluntary employee turnover: Combining variables from the 'traditional' turnover literature with the theory of planned behavior. Journal of Organizational Behavior, 25, 903-914.

Väre, M. (2006). Spousal effect and timing of retirement. Journal of Agricultural Economics, 57, 65-80.

Whelan, K. T., Ehrenberg, R. G., Hallock, K., \& Seeber, K. (2011). The Cornell staff retirement incentive program. Working Paper, Cornell ILR School. Retrieved from: http://digitalcommons.ilr .cornell.edu/do/search/?q=whelan\&fq=virtual _ancestor_link\%3Ahttp\%.

Williams, P., Khan, S., \& Naumann, E. (2011). Customer dissatisfaction and defection:The hidden costs of downsizing. Industrial Marketing Management, 40, 405-413.

Yu, G. C., \& Park, J.-S. (2006). The effect of downsizing on the financial performance and employee productivity of Korean firms. International Journal of Manpower, 27, 230-250.

Zatzick, C., Marks, M., \& Iverson, R. (2009). Which way should you downsize in a crisis? Sloan Management Review, 51(1), 79-86. 